Brit. J. vener. (1956), 32, 159.

\title{
PREVALENCE OF SYPHILIS IN BURMA* ANALYSIS OF SEROLOGICAL DATA ACCUMULATED BY THE WORLD HEALTH ORGANIZATION V.D. CONTROL TEAM, 1951-52
}

\author{
BY \\ HAROLD A. TUCKER \\ Clinical Investigation Section (Infectious Diseases), The Upjohn Company, Kalamazoo, Michigan, U.S.A.
}

Late in 1951, at the request of the Government, the World Health Organization assigned a venereal disease control team to Burma. The team's mission was to extend, within all practicable limits, diagnostic, epidemiologic, and therapeutic activities throughout the Union of Burma. Personnel involved were Anne C. Kimball, serologist (American), Muriel R. Scott, public health nurse (Canadian), and the writer, in the capacities of clinician and administrator. Our role was to work closely with counterpart personnel within the Burmese Government's medical and health services, specifically Dr. Ahad, Director, Pasteur Institute, and Dr. U Thein Maung, Chief of the V.D. Clinic, Rangoon General Hospital, and their associates.

One of the first objectives agreed upon was to survey accessible groups serologically in order to define the magnitude and distribution of the problem. It was our rationale that population samples with the highest prevalences of sero-positivity should later be given priority as facilities for penicillin syphilotherapy were expanded.

At the outset it was found that, because of the widespread civil unrest which then prevailed, our sampling activities would have to be limited to urban areas on regularly scheduled air routes, and to the environs of Rangoon. It was determined that several such areas were the site of prisons. Through the interest of U Maung Gale, Director of Medical and Health Services, and the enthusiastic cooperation of $\mathrm{U}$ Ba Thein, Inspector-General of Prisons, and his entire staff, we were given access to a number of prison populations in Upper and Lower Burma. In the Rangoon area there were numerous clinical facilities concerned with general medical and surgical care (as opposed to those devoted to venereal disease management). Routine admission and prenatal serological examinations were encouraged in these.

\footnotetext{
* Received for publication April 12, 1956.
}

Finally, through the kind cooperation of the American Technical Cooperation Administration (T.C.A.) Health Section, survey data were made available to us for comparative purposes, since in many respects their public health objectives were parallel to our own. A presentation and analysis of these data, necessarily limited as they were, is the purpose of this report.

\section{Materials and Methods}

Samples of serum were obtained from 296 convicts at the Rangoon Central Prison, and from 298 prisoners and 29 warders, clerks, and other staff personnel at the Insein Prison, located approximately 19 kilometres north-east of the centre of Rangoon. In Moulmein, east of Rangoon on the Tenasserim Coast, specimens were obtained from 200 prisoners and 34 of the staff; this facility was remarkable because "bad hats" were routinely transferred there from other prisons. At Akyab Central Prison, located in Western Burma on the Bay of Bengal, sera were obtained from 122 convicts and 21 staff personnel, and in the Mandalay Central Prison, 519 sera were obtained from convicts or "criminal" prisoners, similar to those previously cited in that they had been incarcerated for active breach of the law. In addition a group of $\mathbf{2 7 0}$ "military" prisoners, mainly Karens alleged to be insurgents, who were under restraint pending restoration of civil order, all volunteered to be tested. (It was agreed at the outset that penieillin would be furnished for all seropositive individuals, to be administered by the prison physician.) Thus, these samples comprised 1,435 "criminal" prisoners, 270 "military" ones, and 84 members of prison staffs.

An additional set of data, comprising 10,048 tests, was obtained by analysis of Pasteur Institute records of serologic findings on specimens from eleven medical organizations in Rangoon, which were not primarily devoted to venereal disease diagnosis and control. Hence, an extremely small (but unknown) percentage of positive tests would have represented post-treatment follow-up examinations. Their routine function was a case-finding one, sero-positive patients being referred to the Rangoon General Hospital V.D. Clinic. Most represented routine 
admission, prenatal, and prospective blood-donor specimens from the following institutions:

\begin{tabular}{|c|c|c|c|c|}
\hline \multicolumn{4}{|c|}{ Institution } & Specimens \\
\hline \multicolumn{4}{|c|}{$\begin{array}{l}\text { Evening Mass Education Camp .. } \\
\text { Women's and Children's Welfare Clinics: }\end{array}$} & 499 \\
\hline Bagay's Road . . & we & 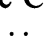 & Is. & 373 \\
\hline Evanson Street & $\cdots$ & $\begin{array}{l}\cdots \\
\cdots\end{array}$ & $\begin{array}{l}\cdots \\
.\end{array}$ & 223 \\
\hline Sandwith Road .. & . & . & .. & 2,108 \\
\hline Mobile Clinic & . & . & . & 301 \\
\hline Lady Rance Clinic .. & & . & . & 778 \\
\hline Baby Welcome Clinic & 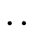 & . & . & 95 \\
\hline Dufferin Hospital ... & & . & . & 3,508 \\
\hline \multicolumn{4}{|c|}{ Rangoon General Hospital: } & \\
\hline Blood Donors & $\ldots$ & . & . & 230 \\
\hline Routine Admissions & . & .. & .. & 1,844 \\
\hline Leprosy Clinic & . & . & . & 89 \\
\hline Total & & . & . & 10,048 \\
\hline
\end{tabular}

Blood was collected by venepuncture, "Vacutainer" equipment being used in outlying areas. Specimens were transported directly to the Pasteur Institute, Rangoon when obtained locally, or were refrigerated, as necessary, and brought in by air from the more distant points. All were screened, using the VDRL (cardiolipin) antigen; doubtful tests were included with the negative results in this report. Quantitative tests by the VDRL and Kahn techniques were later applied to positive sera, but only the qualitative data need be considered here.

\section{Results}

Table I presents the results obtained in the prison surveys; findings in the non-prison groups have been tabulated in Table II, in the order of increasing incidence of sero-positivity.

Samples of a comparable nature were studied by the T.C.A. workers and their findings were similar to those reported here. At the Bassein Central Jail, for example, only 37 sero-positive "military" prisoners were found among 664 tested, a prevalence of 5.6 per cent. Their survey of the Rangoon Police
TABLE II

TABULATION OF POSITIVE VDRL QUALITATIVE SEROLOGICAL TESTS FOR SYPHILIS BY MEDICAL FACILITY IN RANGOON

\begin{tabular}{|c|c|c|c|}
\hline Sample & $\begin{array}{c}\text { Number } \\
\text { Tested }\end{array}$ & $\begin{array}{l}\text { Number } \\
\text { Positive }\end{array}$ & $\begin{array}{l}\text { Per cent. } \\
\text { Positive }\end{array}$ \\
\hline $\begin{array}{l}\text { 1. Rangoon General Hospital, } \\
\text { blood donors } \because \\
\text { 2. Baby Welcome Clinic } \\
\text { 3. Lady Rance Clinic .. } \\
\text { 4. Women and Children Wei- } \\
\text { fare Clinic, Sandwith Rd. } \\
\text { 5. Dufferin Hospital .. } \\
\text { 6. Mobile Clinic } \\
\text { 7. Women and Children Wei- } \\
\text { fare Clinic, Evanson St... } \\
\text { 8. Women and Children Wel, } \\
\text { fare Clinic, Bagay's Rd... } \\
\text { 9. Leprosy Clinic } \\
\text { 10. Evening Mass Education } \\
\text { Camp ... } \\
\text { 11. Rangoon General Hospital, } \\
\text { Routine admission tests.. }\end{array}$ & $\begin{array}{r}230 \\
95 \\
778 \\
2,108 \\
3,508 \\
301 \\
223 \\
373 \\
89 \\
499 \\
1,844\end{array}$ & $\begin{array}{r}10 \\
7 \\
81 \\
448 \\
456 \\
41 \\
31 \\
54 \\
17 \\
101 \\
387\end{array}$ & $\begin{array}{r}4 \cdot 3 \\
7 \cdot 4 \\
10 \cdot 4 \\
10 \cdot 8 \\
13 \cdot 0 \\
13 \cdot 6 \\
13 \cdot 9 \\
14 \cdot 5 \\
19 \cdot 1 \\
20 \cdot 2 \\
21 \cdot 0\end{array}$ \\
\hline Grand Totals $\ldots$ & 10,048 & 1,633 & $16 \cdot 2$ \\
\hline
\end{tabular}

Force showed 53 reactors among 443 men tested ( 12.0 per cent.). In two occupational studies (Hlaing river stevedores and rice-mill labourers), 2,658 specimens were taken, of which 16.6 per cent. were positive. Three attempts to study complete population groups in defined urban areas in or near Rangoon (West Bassein, Talaingyaung, and Athegyi Quarters) showed a prevalence of sero-positivity of 15.9 per cent. among 3,514 individuals tested. It is significant that the T.C.A. teams working in Upper Burma found a comparable picture. In the Bhamo area, $21 \cdot 4$ per cent. of 6,514 sera were positive. Specimens taken in five small urban centres near Mytkyina were found to give reactions in $26 \cdot 2$ per cent. of 4,862. As in our work, the VDRL (cardiolipin) qualitative test was employed.

\section{Discussion}

In the opinion of the writer it would be extremely important to avoid reading too much into these data.

TABLE I

TABULATION OF POSITIVE VDRL QUALITATIVE SEROLOGICAL TESTS FOR SYPHILIS, BY PRISON SAMPLE

\begin{tabular}{|c|c|c|c|c|c|c|c|c|c|c|c|c|}
\hline \multirow{2}{*}{\multicolumn{4}{|c|}{ Sample }} & \multicolumn{3}{|c|}{ "Criminals" } & \multicolumn{3}{|c|}{ Staff } & \multicolumn{3}{|c|}{ “Military" } \\
\hline & & & & \multirow{2}{*}{$\begin{array}{c}\begin{array}{c}\text { No. } \\
\text { Tested }\end{array} \\
296\end{array}$} & \multirow{2}{*}{$\begin{array}{c}\begin{array}{c}\text { No. } \\
\text { Positive }\end{array} \\
107\end{array}$} & \multirow{2}{*}{$\begin{array}{c}\begin{array}{c}\text { Per cent. } \\
\text { Positive }\end{array} \\
36 \cdot 2\end{array}$} & \multirow{2}{*}{$\begin{array}{c}\begin{array}{c}\text { No. } \\
\text { Tested }\end{array} \\
-\end{array}$} & \multirow{2}{*}{$\frac{\begin{array}{c}\text { No. } \\
\text { Positive }\end{array}}{-}$} & \multirow{2}{*}{$\begin{array}{c}\begin{array}{c}\text { Per cent. } \\
\text { Positive }\end{array} \\
-\end{array}$} & \multirow{2}{*}{$\begin{array}{c}\begin{array}{c}\text { No. } \\
\text { Tested }\end{array} \\
-\end{array}$} & \multirow{2}{*}{$\begin{array}{c}\begin{array}{c}\text { No. } \\
\text { Positive }\end{array} \\
-\end{array}$} & \multirow{2}{*}{$\begin{array}{c}\begin{array}{c}\text { Per cent. } \\
\text { Positive }\end{array} \\
-\end{array}$} \\
\hline 1. Rangoon & . & $\ldots$ & . & & & & & & & & & \\
\hline 2. Insein .. & $\ldots$ & $\ldots$ & $\ldots$ & 298 & 54 & $18 \cdot 1$ & 29 & 3 & $10 \cdot 4$ & - & - & - \\
\hline 3. Moulmein & $\ldots$ & $\ldots$ & . & 200 & 29 & $14 \cdot 5$ & 34 & 6 & $17 \cdot 7$ & - & - & - \\
\hline 4. Akyab .. & .. & .. & $\ldots$ & 122 & 18 & $6 \cdot 6$ & 21 & 5 & $23 \cdot 8$ & - & - & - \\
\hline 5. Mandalay & $\ldots$ & $\ldots$ & 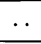 & 519 & 105 & $20 \cdot 2$ & - & - & - & 270 & 12 & $4 \cdot 4$ \\
\hline \multicolumn{2}{|c|}{ Grand Totals } & $\ldots$ & $\ldots$ & 1,435 & 313 & $21 \cdot 8$ & 84 & 14 & $16 \cdot 7$ & 270 & 12 & $4 \cdot 4$ \\
\hline
\end{tabular}


Age, sex distribution, degree of urbanization, distinctive behaviour characteristics of prison populations, and a multitude of similar unknown factors would have influenced these gross findings to some degree. While yaws had only a limited distribution in Burma, leprosy and malaria were comparatively common. Although there may have been some upward bias due to these diseases, it should be noted that the prevalence of sero-positivity in our group of 89 lepers $(19 \cdot 1$ per cent.) was not conspicuously high.

With these limitations in mind, perhaps these data might still justify some cautious generalizations. The prevalence of sero-positivity found by the W.H.O. team was 16.6 per cent. of 11,827 specimens tested. The T.C.A. surveys, embracing a total of 18,655 tests, yielded a comparable figure of $19 \cdot 8$ per cent. It would probably be fair to conclude that, in the populations represented by these samples, the gross prevalence of positive qualitative VDRL tests for syphilis was less than 20 per cent. and well in excess of 10 per cent. This range would probably be a reasonable one for planning purposes, keeping in mind that, for reasons not readily apparent, some population groups would have higher prevalences (e.g., in the Myitkyina area) and others lower ones (e.g., the "military" prison groups).

It was noteworthy that there was so much similarity in prevalences in the different geographic locations represented. Although the prison samples were probably heterogeneous in terms of original residence of the prisoners, the data from the Bhamo and Mytkyina areas showed that there was not a concentration of sero-positivity in the large urban riverine centres, Mandalay and Rangoon. These findings were useful in planning for mass treatment activities, since it seemed obvious that these would eventually have to be extended to the smaller towns and even to rural areas.

\section{Summary}

In 1952, the W.H.O. venereal disease control team in Burma carried out a serological survey in accessible areas in an effort to estimate the prevalence of syphilis. VDRL (cardiolipin) qualitative tests were done on 11,827 specimens of serum from residents of various parts of Burma; 16.6 per cent. were seropositive. On the basis of this and similar data from another source, and taking into account the likely contributions of yaws, malaria, and leprosy, it was concluded that a fair estimate of the prevalence of syphilis would be between 10 to 20 per cent. It was considered remarkable that, within the limits of the data, this prevalence seemed to apply not only in large riverine cities, such as Mandalay and Rangoon, but to the smaller towns and possibly even in some rural areas as well. 